\title{
Diagnosis and Integrated Management of Major Fungal Fruit Rots on Kiwifruit in Korea
}

\author{
*Corresponding author \\ Tel: +82-61-750-3865 \\ Fax: $+82-61-750-3208$ \\ E-mail: youngjin@sunchon.ac.kr \\ ORCID \\ https://orcid.org/0000-0002-3013-1154
}

Received May 18, 2018

Revised June 11, 2018

Accepted June 18, 2018

\author{
Gyoung Hee Kim and Young Jin Koh (D** \\ Department of Plant Medicine, Sunchon National University, Suncheon 57922, Korea
}

\begin{abstract}
Ripe rot, Botrytis storage rot and Sclerotinia rot are major fungal diseases that lead to deterioration of fruit quality in Korea. Ripe rot, which is caused by Botryosphaeria dothidea, affects harvested fruits during poststorage ripening, while Botrytis storage rot, caused by Botrytis cinerea, affects harvested fruits during cold storage, and Sclerotinia rot, caused by Sclerotinia sclerotiorum, mainly affects immature fruits on the trees. Major fungal fruit rots tend to affect yellow- and red-fleshed cultivars of kiwifruit more severely because of the sharp increase in their cultivation acreage in recent years in Korea. In this review, we summarize symptoms and epidemiological characteristics of the major fungal fruit rots and propose integrated management methods of the diseases that can be practically utilized at the farmers' orchards in order to prevent the diseases based on our research works and field experiences and the research works of others conducted during the last three decades worldwide.
\end{abstract}

Keywords: Diagnosis, Fruit rot, Kiwifruit, Management

\section{Introduction}

Kiwifruit is a subtropical fruit trees belonging to the genus Actinidia. There are more than 50 species in the genus Actinidia, most of which originate in the forests of the mountains and hills of southwestern China. Seeds of a wild Actinidia were introduced into New Zealand in 1904. Among the descendants of the first plantings produced from theses seeds used for the development of the kiwifruit industry, cv. Hayward (A. deliciosa) was bred as the first commercial green-fleshed kiwifruit cultivar in the 1920s (Ferguson, 2004; Huang, 2014).

In China, the most widely used name for Actinidia fruit is mihoutao or monkey peach, because wild monkeys are known to enjoy the ripe fruit. The common name in New

Research in Plant Disease

pISSN 1598-2262, elSSN 2233-9191

www.online-rpd.org
Zealand had been Chinese gooseberry, but kiwifruit was proposed as an alternative name for exporting purposes. This name was selected because the kiwi is a symbol of New Zealand and not because of any imagined similarity between the bird and the fruit. Kiwifruit is often shortened to kiwi (Ferguson, 2004; Huang, 2014; Warrington and Weston, 1990).

The first commercial green-fleshed kiwifruit cv. Hayward was introduced in 1977, while the first commercial yellowfleshed kiwifruit cv. Hort16A (A. chinensis) was introduced into Korea in 2004. The name chamdarae has been used for fruits of cv. Hayward produced in Korea in order to differentiate them from imported ones since 1997 (Kim et al., 2013b). However, kiwifruit or kiwi are more generally accepted than chamdarae, because a variety of yellow- and red-fleshed kiwifruit cultivars besides cv. Hort16A are now cultivated in Korea.

In Korea, annual consumption of kiwifruit is approximately 50,000 tons, but its annual production is less than 25,000 
tons and it has a cultivation area of about 1,300 ha. The cultivation area of yellow- and red-fleshed kiwifruit cultivars has been sharply increasing in recent years because of consumers demand for new cultivars with higher sugar content than cv. Hayward, and they now account for approximately $40 \%$ of the total cultivation acreage (Kim et al., 2017; Koh et al., 2017).

Dozens of diseases have impacted kiwifruit in Korea as the cultivation area and diversity of cultivars have increased (Koh, 2008, 2014; The Korean Society of Plant Pathology, 2009). Among these diseases, bacterial canker threatens to kill whole trees or destroy orchards of kiwifruit (Kim et al., 2017; Koh, 2014; Koh et al., 2017). Additionally, fruit rots caused by various fungal pathogens are responsible for severe deterioration of quality of fruits on the trees or harvested fruits during cold storage or post-storage ripening (Koh, 2008, 2014; Koh et al., 2005). Ripe rot, which is caused by Botryosphaeria dothidea, affects harvested fruits during post-storage ripening, while Botrytis storage rot, caused by Botrytis cinerea, affects harvested fruits during cold storage, and Sclerotinia rot, caused by Sclerotinia sclerotiorum, mainly affects immature fruits on the trees (Michailides and Elmer, 2000; Pennycook, 1982, 1985).

In this review, we summarize symptoms and epidemiological characteristics of the major fungal fruits rots affecting kiwifruits and propose integrated management strategies that can be practically applied in farmers' orchards in order to prevent the diseases on the bases of our research works and field experiences and the research works of others conducted during the last three decades worldwide.

\section{Ripe Rot}

Symptoms. Ripe rot caused by B. dothidea develops on fruits of kiwifruits as they are ripening at ambient temperatures, either immediately after harvest or after removal from cold storage. The presence of ripe rot reduces the kiwifruit's shelf-life, directly via the deterioration of flesh quality and the development of unpleasant odors and flavors in affected fruits, and indirectly by the accelerated ripening of adjacent fruits because of ethylene evolution (Pennycook, 1985).

While kiwifruit seeds are immature, the skin and flesh of the fruit act as a protective barrier and aid in limiting animal, insect, and fungal damage. However, as the fruit ripens, it becomes more attractive to animals and insects and more susceptible to rots (Kay and Maguire, 2003).

The first symptoms of ripe rot appear as small shallow brown dimples with 2-5 $\mathrm{mm}$ in diameter on the surface of the infected fruits. These develop into pale brown oval lesions with a dark green margin and sunken parts that look like thumbprint. Lesions of ripe rot expand rapidly into large, pale brown ovals up to $30 \mathrm{~mm}$ long with a narrow, glassy, dark green margin (Koh et al., 2003, 2005; Manning et al., 2003; Pennycook, 1985) (Fig. 1A).

Internally, the fruit tissues are macerated so that the skin peels back easily to expose a zonate lesion consisting of a narrow, water-soaked, green margin surrounding a watersoaked, gas-suffused, whitish oval, often with a small, hard, yellowish, central core corresponding to the tissues underlying the dimple symptom (Koh et al., 2003, 2005; Manning et al., 2003; Pennycook, 1985) (Fig. 1B).

Injuries on fruits caused by insect pests such as the stinkbug are occasionally confused with ripe rot symptoms (Fig. $1 C$, D). Although ripe rot usually affects harvested fruits during post-storage ripening, it occurs on fruits that have been injured by insect pests during the growing season at orchards, and late maturing cultivars are especially vulnerable to insect injury.

Ripe rot is commonly observed on overripe fruits. While the disease does not manifest any clear external symptoms on fruits during ripening, water-soaked fleshed tissues can be seen when the skin of the fruits is peeled off. In addition, milky internal symptoms with a dark green margin developed concentrically as the fruit ripens (Koh et al., 2003, 2005).

Fruits with external symptoms usually have internal symptoms as well. However, a great amount of fruit that appears to be healthy in appearance is often found to have decayed when the skin is peeled off. The gap between the percentage of kiwifruit showing internal and external symptoms often leads to the underestimation of the importance of postharvest ripe rot of kiwifruit, and the necessity for controlling the disease in most farmers' orchards in Korea is still neglected (Koh et al., 2005). Therefore, internal symptoms should be checked in fruits without external symptoms during investigations of ripe rot.

Epidemiological characteristics. Several fungi were reported to be associated with ripe rot of kiwifruit (Beraha, 1970; Hawthorne et al., 1982; Pennycook, 1981; Sommer and Beraha, 1975; Tanbara, 1988), among which B. dothidea is 

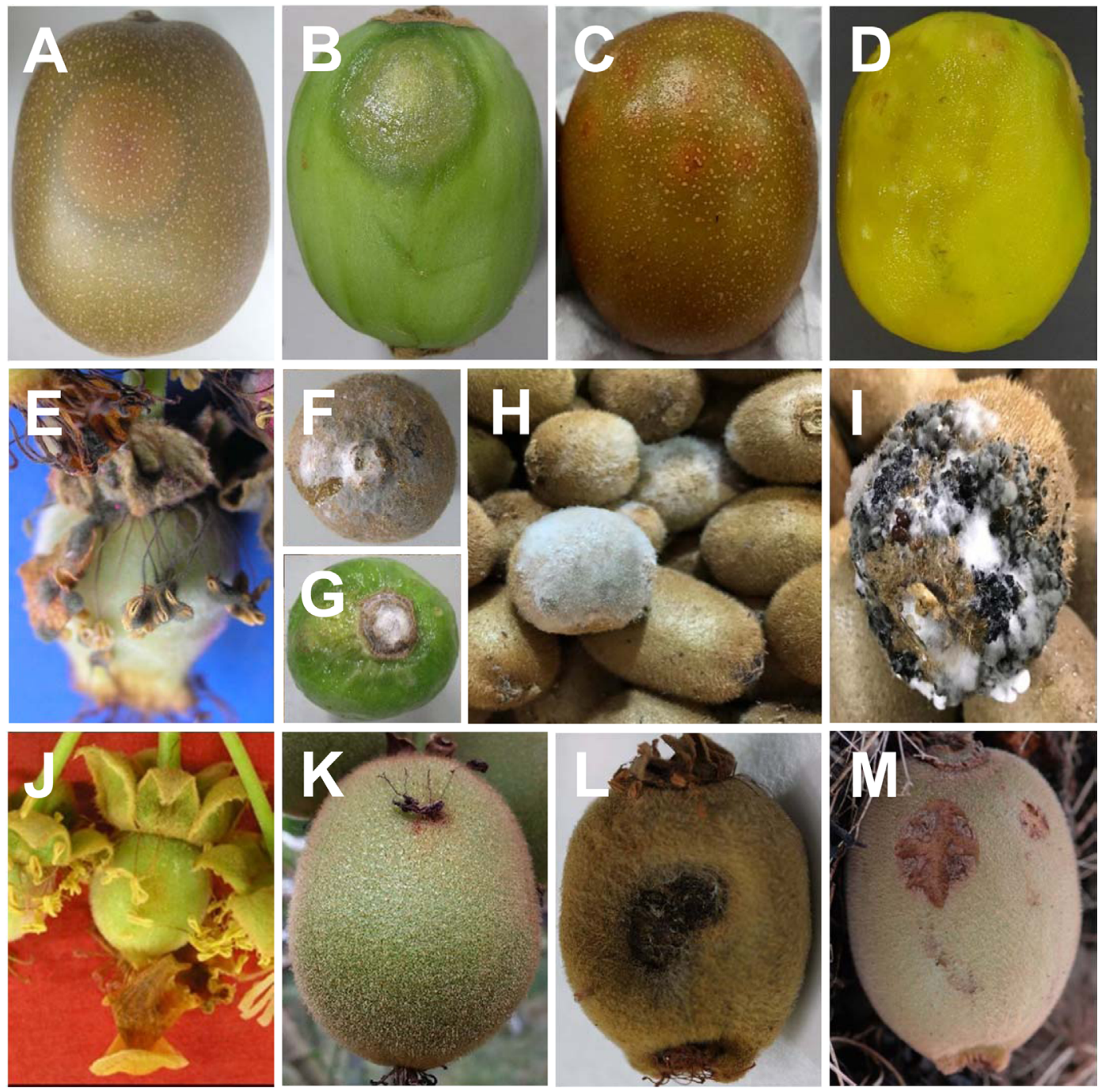

Fig. 1. Symptoms of major fungal fruit rots on kiwifruit. (A, B) external and internal symptoms of ripe rot on fruit caused by Botryosphaeria dothidea, $(C, D)$ external and internal symptoms of injuries on fruit by stinkbug, $(E)$ gray mold symptoms on senescing flowers caused by Botryotis cinerea, $(\mathrm{F}, \mathrm{G})$ external and internal symptoms of stem-end rot on fruit caused by $B$. cinerea, $(\mathrm{H})$ secondary rot caused by $B$. cinerea from rotten fruits to adjacent fruits in the storage tray, (I) breakdown rot on fruit caused by $B$. cinerea associated with a number of fungal pathogens, $(J)$ earliest symptom of Sclerotinia rot on young fruit, $(K)$ Sclerotinia rot-infected senescing stamens and petals attached to the shoulder of young fruit, (L) large, deeply scarring lesion on young fruit caused by S. sclerotiorum, (M) scarring lesion with irregular tears on fruit caused by S. sclerotiorum.

the major pathogen causing ripe rot on fruits after harvest (Manning et al., 2003; Pennycook, 1985). In samples of cv. Hayward from the Te Puke district of New Zealand, up to $15 \%$ of fruits were found to have distinctive, early symptoms of ripe rot caused by Botryosphaeria (Pennycook, 1981).

The average overall disease incidence of ripe rot of cv. Hayward produced at major cultivation areas in Korea was 32\%, but the incidence ranged from $5 \%$ at a sprayed orchard to $68 \%$ at an unsprayed one among 16 orchards surveyed in 2000. B. dothidea was also identified as the major pathogen causing ripe rot with an average isolation rate of $83.3 \%$ from the diseased fruits in Korea (Koh et al., 2005).

Incidences of ripe rot on fruits vary among cultivars. Yellow- and red-fleshed kiwifruit cultivars are more susceptible to the disease than green-fleshed ones. This may be because their fruits have higher sugar contents and lower acidity, which is favorable for the growth of $B$. dothidea.

$B$. dothidea is a cosmopolitan fungus with a wide host range. In kiwifruit orchards, ascomata and pycnidia have been found in the bark of dead twigs and branches of shelter 
trees and prunings of kiwifruit left to lie on the ground as the most abundant inoculum source in New Zealand (Kay and Maguire, 2003; Pennycook, 1985).

B. dothidea usually infects young fruits by wind-borne ascospores which are discharged into the air during warm, wet weather for about two months after pollination. The spores, an alternative potential inoculum source, are produced in slimy masses that are distributed over only relatively short distances by rain splash. The infections remain completely symptomless until the fruits begin to ripen (Pennycook, 1985).

Usually, harvested fruits are maintained in commercial cold storage at $0 \pm 1^{\circ} \mathrm{C}$ for $1-6$ months to prevent ripening because the low temperatures protect fruits from attack by the postharvest fruit rot pathogens such as $B$. dothidea during storage (Schroeder and Fletcher, 1967).

Integrated management. Elimination of kiwifruit prunings could reduce the amount of $B$. dothidea inoculum present in the orchard, since prunings of kiwifruit left to lie on the ground are the most abundant inoculum source.

Canopy management is creating an environment within the canopy that is less favorable for infection and survival of B. dothidea, which is favored by shaded, warm, moist conditions. Orchard management strategies that maximize tree health and minimize tree stress limits the likelihood of fruit developing rots, since stressed tree will be more susceptible to infection by $B$. dothidea. Nutrition and water stress have been identified as particularly important factors inducing the disease (Kay and Maguire, 2003).

Careful handling is necessary to keep fruits healthy without wounds during harvest, storage, packing and marketing because skin wounds might play a role in providing route for $B$. dothidea to enter the fruits and accelerate the ripening process. Control of stinkbugs using pheromone traps is also useful to prevent wound injuries on fruits. Bagging fruits one week after anthesis helps prevent $B$. dothidea infections and insect injuries to fruits (Huang, 2014).

Although kiwifruits were ripened in a short period at higher temperatures, the optimum conditions for kiwifruit ripening to incur the least damage from ripe rot are considered to be 20 -days of ripening at $17^{\circ} \mathrm{C}$ (Koh et al., 2005).

Chemical ripening aides such as ethylene generators (Shiraishi Calcium Co. Ltd., Osaka, Japan) can also be utilized to effectively reduce ripening period and suppress postharvest decays and ripe rot in the future (leki and Yamanaka, 1991).

Fungicide application is the most important measure for preventing ripe rot (Eckert and Ogawa, 1988; Hawthorne and Reid, 1982; Kim et al., 2013a; Koh et al., 2005; Tanbara, 1988). Five fungicides are registered for use on kiwifruit ripe rot to spray 3-5 times from early June at 10-day intervals in Korea (Table 1) (Korea Crop Protection Association, 2017). The first spray time of the fungicides on early June was deduced from the onset of $B$. dothidea infections on young fruits of cv. Hayward. However, it is reasonable to adjust spraying of the fungicides to immediately after petal fall of each cultivar, since yellow- and red-fleshed kiwifruit cultivars bloom two or three weeks earlier than cv. Hayward (Kim et al., 2013a).

\section{Botrytis Storage Rot}

Symptoms. B. cinerea does not easily establish infections on healthy tissue, but readily colonizes damaged, senescing or dead plant tissues such as flowers parts including petals, sepals and styles (Fig. 1E), blown-out canes, green leaves with dead brown tissue, dead leaves, and occasionally prunings and fallen fruit.

Table 1. Fungicides registered for the control of ripe rot on kiwifruit in Korea

\begin{tabular}{lcccc}
\hline \multicolumn{1}{c}{ Fungicides } & Dosage & Spray time and interval & Option for safe use \\
\hline Iminoctadine tris (albesilate) WP & $20 \mathrm{~g} / 20 \mathrm{~L}$ & Spray up to 5 times at 10-day intervals from early June & Spray until 30 days before harvest \\
Benomyl WP & $13 \mathrm{~g} / 20 \mathrm{~L}$ & Spray up to 3 times at 10-day intervals from early June & Spray until 21 days before harvest \\
Tebuconazole EC & $10 \mathrm{ml} / 20 \mathrm{~L}$ & Spray up to 3 times at 10-day intervals from early June & Spray until 30 days before harvest \\
Thiophanate-methyl WP & $20 \mathrm{~g} / 20 \mathrm{~L}$ & Spray up to 5 times at 10-day intervals from early June & Spray until 10 days before harvest \\
Azoxystrobin difenoconazole EC & $4 \mathrm{ml} / 20 \mathrm{~L}$ & Spray up to 4 times at 10-day intervals from early June & Spray until 14 days before harvest \\
\hline
\end{tabular}

WP, wettable powder; EC, emulsifiable concentrate.

Korea Crop Protection Association (2017). 
Young fruits can be infected by $B$. cinerea spores on retained stamens and petals after anthesis, and heavy infection may cause fruit drop. Fruit hairs of the infected young fruitlets become brown, after which the whole fruit becomes brown, causing a decrease in quality. If the diseased stamens and petals adhere to the leaf surface, the disease spreads to the leaves and causes brown ring-like lesions on leaves that are initially $2-3 \mathrm{~cm}$ in diameter but extending gradually until the diseased leaves fall (Huang, 2014).

$B$. cinerea causes three kinds of storage rots in kiwifruit during cold storage. Harvested fruits that have been graded and packed as healthy and unblemished-looking fruits will often develop various storage rot symptoms during commercial cold storage at $0^{\circ} \mathrm{C}$ (Pennycook, 1985; Tanbara, 1988).

The most common Botrytis storage rot is stem-end rot which develops from Botrytis contamination of the picking wound at or soon after harvesting. Secondary rot is caused when the fungus spreads from rotten fruit to adjacent fruit in the tray. Later, when the storage life of the fruits is coming to an end, breakdown rot, which is associated with a number of fungal pathogens, develops (Huang, 2014; Pennycook, 1985; Warrington and Weston, 1990).

The stem-end rot symptoms first begin to appear after 3 to 4 weeks of cold storage (Fig. 1F). A conspicuous external darkening commences at the stem end of the fruit, and advances with a straight, sharply defined front. This results in the classic tide mark on the outside of the fruit. The diseased fruit flesh is glassy and water-soaked and often discolored faint pinkish-fawn (Fig. 1G) (Michailides and Elmer, 2000; Pennycook, 1985).

Initially, there is little or no visible fungal growth on the outside of the rotting fruit. However, an uneven, fluffy, dull white layer of mycelium may develop on the skin of the affected portion of the fruit as the infection progresses. The white mycelium usually resembles the typical white mold of S. sclerotiorum, rather than the gray mold commonly associated with Botrytis infections (Pennycook, 1985).

After prolonged cold storage, the mycelium may assume a gray, fuzzy appearance, because of the growth of tufts with dark conidiophores bearing numerous, powdery, gray spores; in other instances, the mycelium may aggregate to form small, flat, irregularly shaped, black sclerotia that are closely appressed to the fruit surface. An external mycelium frequently spreads to adjacent fruits within the tray, ultimately causing secondary infections (Fig. 1H). Secondary rotting results in the complete breakdown rot of the fruit, which is associated with a number of fungal pathogens (Fig. 11) (Michailides and Elmer, 2000; Pennycook, 1985).

Epidemiological characteristics. Incidence of Botrytis storage rot in kiwifruit is unpredictable and highly variable, not only from year to year and from orchard to orchard, but even between fruits picked from the same trees on different days. Up to $32 \%$ incidence of primary stem-end rot has been observed in New Zealand and an incidence of greater than $50 \%$ was reported from extreme cases in Italy (Bisiach et al., 1984; Huang, 2014; Pennycook, 1985). However, direct fruit losses of 0.2 to $2 \%$ caused by Botrytis storage rot are more common (Michailides and Elmer, 2000). In Korea, Botrytis storage rot was also reported as one of the most detrimental postharvest diseases (Koh et al., 2003).

$B$. cinerea is a cosmopolitan fungus causing gray mold on fruits of numerous crops (Agrios, 2005). B. cinerea survives as dormant mycelium or small, hard, black sclerotia over the winter. Early in the growing season, the majority of the inoculum is produced on overwintering mycelium on prunings on the ground or occasionally sclerotia on prunings. At full bloom, senescent male flowers and prunings are the main inoculum sources (Michailides and Elmer, 2000).

During blossom, petals and anthers become infected, after which these tissues provide the inoculum for sepal and receptacle infections. B. cinerea often becomes conspicuous in kiwifruit orchards during late blossom and petal fall. The key factor influencing $B$. cinerea infection is the rain, especially during petal fall (Huang, 2014).

During wet weather, leaf lesions may develop from secondary spread via adherence of debris from infected blossoms. However, kiwifruit blossom infections only have an indirect influence on stem-end rot by increasing the amount of Botrytis inoculum present in the orchards (Michailides and Elmer, 2000; Pennycook, 1985).

By mid-fruit development, senescing wind-damaged shoots are the main inoculum sources. These tissues function as an inoculum bridge for later infection of green, senescing, and dead leaves in the canopy. By harvest, the green leaves with necrosis and dead leaves are the primary inoculum sources, while the hairy kiwifruit acts as a natural conidia trap. At the time of harvest, spores in the skin surface contaminate the picking scar which leads to stem-end rot in cold storage (Michailides and Elmer, 2000; Pennycook, 1985). 
Fruit infection occurs during harvesting, grading, and packing operations via direct Botrytis contamination of the picking wound that is formed where the fruit is snapped from its pedicel (Michailides and Elmer, 2000; Pennycook, 1985). Although the optimum temperature for mycelial growth of $B$. cinerea is $23^{\circ} \mathrm{C}$, the fungus still grows slowly at $0^{\circ} \mathrm{C}$ and its mycelial colony reaches up to $9 \mathrm{~cm}$ in diameter 40 days after incubation on potato dextrose agar (Bisiach et al., 1984). Therefore, long storage of kiwifruit for 4 to 6 months may lead to outbreaks of Botrytis storage rot in cold storage.

The low concentrations of ethylene produced from the fruits affected by $B$. cinerea during cold storage may reduce the storage life of healthy fruits within the same tray. Such fruits also tend to have a reduced post-storage shelf-life and to undergo more rapid onset of ripe rot compared with similar fruits from trays unaffected by $B$. cinerea (Pennycook, 1985).

Integrated management. Elimination of kiwifruit prunings could reduce the amount of inoculum of $B$. cinerea present in the orchard, since prunings of kiwifruit left to lie on the ground are the most abundant inoculum source. Grass and weed debris and other ground litter should be eliminated, since they can be niche for saprophytic growth of $B$. cinerea.

Canopy management creates an environment within the canopy that is less favorable for infection and survival of $B$. cinerea, which is favored by shaded, warm, moist conditions. Minimizing fruit handling will reduce Botrytis infections, since postharvest handling of the fruit such as picking, grading and packing allows the transfer of spores from the surface of one fruit onto the picking wounds of adjacent fruit, resulting in a potential infection. Fishing net type bags may reduce Botrytis build-up in the bag since the canvas picking bags can become contaminated with Botrytis spores attached to kiwifruit hairs (Michailides and Elmer, 2000).

Holding or curing the fruit at ambient temperatures before packing and cold storage significantly decreases Botrytis stem-end rot because fruits rapidly cooled to $0^{\circ} \mathrm{C}$ (forced air cooling) develop more Botrytis storage rot during cold storage than those that have been passively cooled. The best treatment for reduction of Botrytis storage rot is $48 \mathrm{~h}$ delayed cooling at $15^{\circ} \mathrm{C}$, high $(2 \mathrm{~m} / \mathrm{s})$ air velocity, and $95 \%$ relative humidity. The use of controlled atmospheres (CA) of $2.5 \%$ oxygen and $5 \% \mathrm{CO}_{2}$ slowdown ripening and thus, the fungal infection considerably since Botrytis storage rot develops in cold storage as kiwifruits start ripening (Michailides and Elmer, 2000).

Fumigation of fruit with $\mathrm{SO}_{2}$ reduces gray mold in cold storage, and complete control was achieved at 16,600 to $3,200 \mu \mathrm{l} / \mathrm{g}$ without any fruit injury (Cheah et al., 1992a). Fruit hot water dips of fruit at $46^{\circ} \mathrm{C}$ for $15 \mathrm{~min}$ and $48^{\circ} \mathrm{C}$ for $8 \mathrm{~min}$ were found to provide almost complete disease control without heat injury on fruit firmness (Cheah et al., 1992b).

Kiwifruit containers and storage bins should be surfacesterilized prior to use in cold storage. Moreover, fruit needs to be condition checked during cold storage. The optimum time for condition checking is after 10-12 weeks of cold storage, by which time almost all the primary infections will have produced visible symptoms (Michailides and Elmer, 2000).

Fungicide application is the most effective control measure of Botrytis storage rot (Pyke et al., 1994). Four fungicides are registered in Korea to spray 3-4 times from onset of gray mold at 7- or 10-day intervals to control Botrytis storage rot on kiwifruit (Table 2) (Korea Crop Protection Association, 2017). However, it is very difficult for kiwifruit growers to detect the disease onset and to determine the optimum spray time. Therefore, it is reasonable to adjust the time of fungicide application to the late blossom-early petal fall, when

Table 2. Fungicides registered for the control of gray mold on kiwifruit in Korea

\begin{tabular}{|c|c|c|c|}
\hline Fungicides & Dosage & Spray time and interval & Option for safe use \\
\hline Boscalid·fludioxonil SC & $10 \mathrm{ml} / 20 \mathrm{~L}$ & $\begin{array}{l}\text { Spray up to } 5 \text { times at 7-day intervals from onset of } \\
\text { gray mold }\end{array}$ & Spray until 14 days before harves \\
\hline Iprodione WP & $20 \mathrm{~g} / 20 \mathrm{~L}$ & $\begin{array}{l}\text { Spray up to } 4 \text { times at 10-day intervals from onset of } \\
\text { gray mold }\end{array}$ & Spray until 14 days before harves \\
\hline Carbendazim.diethofencarb WP & $20 \mathrm{~g} / 20 \mathrm{~L}$ & Spray up to 3 times at 10-day intervals from early June & Spray until 21 days before harves \\
\hline Fluopyram SC & $5 \mathrm{ml} / 20 \mathrm{~L}$ & Spray up to 3 times at 10-day intervals from early June & Spray until 14 days before harves \\
\hline
\end{tabular}

SC, suspension concentrate; WP, wettable powder; EC, emulsifiable concentrate.

Korea Crop Protection Association (2017). 
Botrytis infections begin.

\section{Sclerotinia Rot}

Symptoms. During the growing season, S. sclerotiorum affects flowers, shoots and leaves of both male and female kiwifruit trees and developing fruits (Pennycook, 1982). Sclerotinia disease of flowers has been referred to as Sclerotinia rot (Warrington and Weston, 1990) and blossom blight (Pennycook, 1982), but diseased fruitlets can also be used because the symptoms appear on fruitlets 10-14 days after flowering (Hoyte, 2001). Soft rot of fruit on trees is referred to as field rot, while dry lesions on fruit are termed as scarring (Pennycook, 1982; Warrington and Weston, 1990) and disease on shoots, where girdling causes death of the shoot beyond the lesion, has been termed as twig blight (Ford, 1971). However, in this review, Sclerotinia rot is used to refer to the major rot that affects immature fruits hanging on the kiwifruit trees to mature (Pennycook, 1982).

The earliest symptom of Sclerotinia rot is a blossom blight during bloom season. Blossoms and their pedicels turn pale brown and wither (Fig. 1J). These symptoms are common on male vines, and entire clusters of male blossoms degenerate into a tangled mass, while female buds and blossoms are less frequently affected (Pennycook, 1985). Sometimes, the symptoms are confused with those of bacterial blossom rot (Koh et al., 1993).

During dry seasons, the withered blossoms become dry and crisp with little or no mycelium apparent, and no secondary spread of infection occurs. In wet seasons, the rotting blossoms remain soft and mushy, and become covered with copious white mycelium. The mycelium often aggregates into dense knots, which may darken and harden to form sclerotia. The rot lesions frequently progress from the pedicels into the shoots, and destructive secondary spread is common where rainfall-soaked infected blossoms adhere to shoots, leaves, and petioles (Pennycook, 1985).

Field rot symptoms are observed from 2 weeks after petalfall. The rot initially appears as a small pale green, watersoaked lesion on the fruit surface that is often associated with blossom debris such as senescing stamens and petals attached to the shoulder, side or basal areas of the fruit (Fig. $1 \mathrm{~K})$. Under continuously wet conditions, the rot will progress and cause young fruits affected by large, deeply scarring lesions to drop within a week or two of infection (Fig. 1L).
A change in environmental conditions, and/or the plant's natural defense mechanisms, can delay progression of the rot, resulting in scarring of the fruit surface. Scars consists of irregular tears that range from superficial (3-4 $\mathrm{mm}$ across) to severe (up to $20-40 \mathrm{~mm}$ in length) according to the growth of fruit (Fig. 1M). Although the affected fruits grow well on the trees of kiwifruit in the field, irregular scars remain badly on the harvested fruits, impairing fruit quality.

Postharvest rot symptoms caused by S. sclerotiorum were observed on stored kiwifruit in May 2014 in Jinju, Korea. The rot appeared as soft, water-soaked lesions on fruits covered with a white mycelium (Lee et al., 2015). Sclerotinia rot is not common in cold storage.

Epidemiological characteristics. In the past, Sclerotinia rot has often been mistakenly considered as that caused to infection by B. cinerea (Michailides and Elmer, 2000). Seasonal incidence of field rot is dependent on the frequency and duration of periods of rainy season conducive to the establishment of infection by Sclerotinia ascospores. Crop loss typically ranges from $0-4 \%$. However, an estimated $5 \%$ loss of immature fruits was reported from the Te Puke district of New Zealand after a severe Sclerotinia infection period in 1980 and crop loss exceeded 15\% in high risk blocks (Pennycook, 1985).

S. sclerotiorum overwinters in kiwifruit orchards as sclerotia in the soil. Some of the sclerotia will have developed on diseased kiwifruit blossoms and fruits during the previous summer. However, their major source is probably saprophytic growth of the fungus on grass and weed debris and other ground litter, since the fungus has a very wide host range (Agrios, 2005; Pennycook, 1985).

After a period of winter dormancy, sclerotia germinate during spring and summer in response to moisture and rising soil temperatures (Wiletts and Wong, 1980). Apothecia grow from the sclerotia up through the soil and litter. Changes in atmospheric humidity or pressure trigger puffing, the simultaneous discharge of thousands of ascospores from the upper, fertile surface of an apothecium (Hartill and Underhill, 1976).

Discharged ascospores are dispersed by wind and deposited on the vines as ascospore showers. Ascospores cannot directly infect healthy green tissues such as leaves and fruit but will readily infect senescing or dying tissues. Therefore, fruit infections only occur if ascospores are deposited at in- 
fection sites that are in direct contact with an adequate food base (e.g., senescing stamens and petals, or water droplets containing pollen grains or pollen exudates) for saprophytic growth, and if those infection sites subsequently remain wet for several hours (Willetts et al, 1980). Once the fungus is established in tissues, it is then able to penetrate and infect healthy tissues. There is no secondary spread from fruit lesions because the pathogen does not produce conidia (Pennycook, 1985).

Incidences of Sclerotinia rot on fruits varied among cultivars. Yellow- and red-fleshed kiwifruit cultivars are more vulnerable to the disease than green-fleshed ones. The rot initially develops as a lesion on the fruit surface caused by blossom debris such as senescing stamens and petals attached to the shoulder, side or basal areas of the fruit. Greenfleshed kiwifruit cultivars have much longer hairs than yellow- and red-fleshed ones. Long hairs hinder attachment of blossom debris on the skin of the fruit on green-fleshed kiwifruit cultivars, but not onto that of yellow- and red-fleshed ones.

Integrated management. The risk of Sclerotinia infection can be reduced by removal of senescent blossom tissues from the trees. A vigorous air-blast spray application at petal fall will help dislodge the senescent petals and stamens of the female flowers from the newly set fruits (Pennycook, 1985). Grass and weed debris and other ground litter should be also removed, since they can be niche for saprophytic growth of S. sclerotiorum.

Male vines should be pruned as soon as possible after pollination, to eliminate the senescent male blossoms. General pruning for a relatively open canopy will also reduce the risk of infection by allowing the vines to dry more quickly after rain (Pennycook, 1985). Access to sunlight and air circulation are important to minimizing Sclerotinia infection.

Kiwifruit leaves treated with salicylic acid and other chemically related derivatives reduce lesion expansion of Sclerotinia rot because of stimulation of the kiwifruit's own defense mechanisms by pretreatment with elicitors (Reglinski et al., 1997).

A selected isolate of Epicoccum nigrum for biological control of Sclerotinia rot has good efficacy against S. sclerotiorum, but it is likely that the timing and number of applications needs to be studied further to ensure consistent and costeffective disease control. Ultimately, the best disease control will be achieved by combining E. nigrum with complementary modes of action and integration with other cultural control strategies (Elmer et al., 2005).

In Korea, four fungicides are registered for use on kiwifruit Sclerotinia rot to spray 3-4 times at 10-day intervals 14 days before harvest, but their application times differ (Table 3) (Korea Crop Protection Association, 2017). It is recommended that azoxistrobin and fenpyrazamine be sprayed from early disease onset, while iprodione is recommended for use during severe epidemics and fluopyram is recommended for use prior to bloom. However, the optimum application time of the fungicides will be adjusted to be at late blossom-early petal fall when Sclerotinia rot begins to occur.

The fungicides are extremely effective against $S$. sclerotiorum if their application is timed to coincide with the deposition of ascospore showers. In some seasons, a single, thorough application at late blossom-early petal fall to prevent saprophytic colonization of senescing blossom tissues may be sufficient. However, in a wet season, additional applica-

Table 3. Fungicides registered for the control of Sclerotinia rot on kiwifruit in Korea

\begin{tabular}{|c|c|c|c|}
\hline Fungicides & Dosage & Spray time and interval & Option for safe use \\
\hline Azoxystrobin WP & $20 \mathrm{~g} / 20 \mathrm{~L}$ & $\begin{array}{l}\text { Spray up to } 3 \text { times at 10-day intervals from onset of } \\
\text { Sclerotinia rot }\end{array}$ & Spray until 14 days before harvest \\
\hline Iprodione WP & $20 \mathrm{~g} / 20 \mathrm{~L}$ & $\begin{array}{l}\text { Spray up to } 4 \text { times at severe epidemics of } \\
\text { Sclerotinia rot }\end{array}$ & Spray until 14 days before harvest \\
\hline Fenpyrazamin WG & $20 \mathrm{~g} / 20 \mathrm{~L}$ & $\begin{array}{l}\text { Spray up to } 3 \text { times at 7-day intervals from onset of } \\
\text { Sclerotinia rot }\end{array}$ & Spray until 30 days before harvest \\
\hline Fluopyram SC & $5 \mathrm{ml} / 20 \mathrm{~L}$ & $\begin{array}{l}\text { Spray up to } 3 \text { times at 10-day intervals before } \\
\text { flowering }\end{array}$ & Spray until 14 days before harvest \\
\hline
\end{tabular}

WP, wettable powder; WG, water dispersible granule; SC, suspension concentrate.

Korea Crop Protection Association (2017). 
tions may be necessary during blossom and after petal fall.

\section{Conclusions}

Major fungal fruit rots tend to affect yellow- and redfleshed kiwifruit cultivars of kiwifruit more severely as a result of sharp increases in their cultivation acreage in recent years in Korea. This might be related to cultivar characteristics. Fruits of yellow- and red-fleshed kiwifruit cultivars have much higher levels of sugar and lower acidity than those of green-fleshed ones, which are conducive to fungal infections such as ripe rot. However, fruits of green-fleshed kiwifruit cultivars have longer hairs than those of yellow- and red-fleshed ones, which are unfavorable to Sclerotinia rot infections.

Although Sclerotinia rot usually affects fruits in the field, most of the fungal fruit rots occur in cold storage after harvest. Some of the diseases are associated with each other via complicated relationships. Therefore, the best method of avoiding the potential economic damage caused by major fungal fruit rots may be combined effective control of each of the diseases in cold storage, scrupulous quality control during grading and packing to improve the general storage quality of kiwifruit, and careful handling throughout the distribution chain to ensure that ripening is not accelerated at too early a stage (Pennycook, 1985).

In addition to major fungal fruit rots, several diseases affecting fruits after harvest were also reported to occur in other kiwifruit growing countries in recent years (Kay and Maguire, 2003; Manning et al., 2003; Pennycook and Samuels, 1985). Although these diseases have not yet been reported in Korea until now, similar symptoms are occasionally observed in the field or cold storage. Therefore, further studies are needed to survey the etiology and epidemiology of the diseases in order to develop the effective strategies for their management in the future.

\section{Conflicts of Interest}

No potential conflict of interest relevant to this article was reported.

\section{References}

Agrios, G. N. 2005. Plant pathology. 5th ed. Elsevier Academic Press, Burlington, MA, USA. 922 pp.
Beraha, L. 1970. Stem-end rot of Chinese gooseberry (Actinidia chinensis) on the market. Plant Dis. Report. 54: 422-423.

Bisiach, M., Minervini, G. and Vercesi, A. 1984. Biological and epidemiological aspects of the kiwi fruit (Acitinidia chinenesis Planchon) rot, caused by Botrytis cinerea Pers. Rivista Patologia Vegetale 20: 38-55.

Cheah, L. H., Hunt, A. W. and Burge, G. K. 1992a. Sulpur dioxide fumigation for control of Botrytis storage rot of kiwifruit. N. Z. J. Crop Hortic. Sci. 20: 173-176.

Cheah, L. H., Irving, D. E., Hunt, A. W. and Corrigan, V. K. 1992b. Effect of hot water dips on botrytis storage rot and quality of kiwifruit. Postharvest Biol. Technol. 2: 1-6.

Eckert, J. W. and Ogawa, J. M. 1988. The chemical control of postharvest diseases: deciduous fruit, berries, vegetables and root/ tuber crops. Annu. Rev. Phytopathol. 26: 433-469.

Elmer, P. A. G., Hoyte, S. M., Vanneste, J. L., Reglinski, T., Wood, P. N. and Parry, F. J. 2005. Biological control of fruit pathogens. N. Z. Plant Prot. 58: 47-54.

Ferguson, A. R. 2004. 1904-the year that kiwifruit (Actinidia deliciosa) came to New Zealand. N. Z. J. Crop Hortic. Sci. 32: 3-27.

Ford, I. 1971. Chinese gooseberry pest and disease control. N. Z. J. Agric. 122: 86-89.

Hartill, W. F. T. and Underhill, A. P. 1976. "Puffing” in Sclerotinia sclerotiorum and Sclerotinia minor. N. Z. J. Bot. 14: 355-358.

Hawthorne, B. T. and Reid, M. S. 1982. Possibility for fungicidal control of kiwifruit fungal storage rots. N. Z. J. Exp. Agric. 10: 333336.

Hawthorne, B. T., Rees-George, J. and Samuels, G. J. 1982. Fungi associated with leaf spots and post-harvest fruit rots of kiwifruit (Actinidia chinensis) in New Zealand. N. Z. J. Bot. 20: 143-150.

Hoyte, S. 2001. Epidemiology and management of Sclerotinia sclerotiorum (lib.) de Bary in kiwifruit (Actinidia deliciosa (A. Chev.)). Ph. D. thesis. Massey University, Palmerston North, New Zealand.

Huang, H. 2014. The genus Actinidia: a world monograph. Science Press, Beijing, China. 317 pp.

leki, H. and Yamanaka, Y. 1991. Reduction of kiwifruit ripe rot by accelerated chemical ripening at low temperatures. N. Z. J. Crop Hortic. Sci. 19: 399-403.

Kay, S. and Maguire, K. 2003. Rots of Hort16A. Zespri International Ltd., Mount Maunganui, New Zealand. 7 pp.

Kim, G. H., Jung, J. S. and Koh, Y. J. 2017. Occurrence and epidemics of bacterial canker of kiwifruit in Korea. Plant Pathol. J. 33: 351361.

Kim, G. H., Lee, Y. S., Jung, J. S., Hur, J. S. and Koh, Y. J. 2013a. Optimal spray time, interval and number of preventive fungicides for the control of fruit rots of green and gold kiwifruit cultivars. Res. Plant Dis. 19: 1-6. (In Korean)

Kim, S. C., Seong, K. C., Choa, J. H., Lim, C. K., Chun, S. J., Kim, C. H. et al. 2013b. David and Goliath. RDA Interrobang 111: 1-20. (In Korean)

Koh, Y. J. 2008. Understandable diseases, pests and physiological 
disorders of kiwifruit. Joongang Life Publishing Co., Seoul, Korea. 149 pp. (In Korean)

Koh, Y. J. 2014. Battling bacterial canker of kiwifruit. Hapdong Printing, Jeonju, Korea. 279 pp. (In Korean)

Koh, Y. J., Chung, H. J. and Kim, J. H. 1993. Blossom rot of kiwifruit caused by Pseudomonas syringae. Plant Pathol. J. 9: 300-303. (In Korean)

Koh, Y. J., Hur, J. S. and Jung, J. S. 2005. Postharvest fruit rots of kiwifruit (Actinidia deliciosa) in Korea. N. Z. J. Crop Hortic. Sci. 33: 303310.

Koh, Y. J., Kim, G. H. and Jung, J. S. 2017. A proposed manual for the efficient management of kiwifruit bacterial canker in Korea. Res. Plant Dis. 23: 1-18.

Koh, Y. J., Lee, J. G., Lee, D. H. and Hur, J. S. 2003. Botryosphaeria dothidea, the causal organism of ripe rot of kiwifruit (Actinidia deliciosa) in Korea. Plant Pathol. J. 19: 227-230.

Korea Crop Protection Association. 2017. 2017 Guide book of pesticides. Korea Crop Protection Association, Seoul, Korea. 1568 pp. (In Korean)

Lee, J. H., Kwon, Y. H., Kwack, Y. B. and Kwak, Y. S. 2015. Report of postharvest rot of kiwifruit in Korea caused by Sclerotinia sclerotiorum. Int. J. Food Microbiol. 206: 81-83.

Manning, M. A., Meier, X., Olsen, T. L. and Johnston, P. R. 2003. Fungi associated with fruit rots of Actinidia chinensis 'Hort16A' in New Zealand. N. Z. J. Crop Hortic. Sci. 31: 315-324.

Michailides, T. J. and Elmer, P. A. G. 2000. Botrytis gray mold of kiwifruit caused by Botrytis cinerea in the United States and New Zealand. Plant Dis. 84: 208-223.

Pennycook, S. R. 1981. Ripe rot of kiwifruit caused by Botryosphaeria dothidea. Orchardist N. Z. 54: 392-394.
Pennycook, S. R. 1982. Sclerotinia rot of kiwifruit (Actinidia chinensis). Orchardist N. Z. 55: 407-408.

Pennycook, S. R. 1985. Fungal fruit rots of Actinidia deliciosa (kiwifruit). N. Z. J. Exp. Agric. 13: 289-299.

Pennycook, S. R. and Samuels, G. J. 1985. Botryosphaeria and Fusicoccum species associated with ripe fruit rot of Actinidia deliciosa (kiwifruit) in New Zealand. Mycotaxon 24: 445-458.

Pyke, N. B., Manktelow, D. G., Elmer, P. A. G. and Tate K. G. 1994. Postharvest dipping of kiwifruit in iprodione to control stem-end rot caused by Botrytis cinerea. N. Z. J. Crop Hortic. Sci. 22: 81-86.

Reglinski, T., Poole, P. R., Whitaker, G. and Hoyte, S. M. 1997. Induced resistance against Sclerotinia sclerotiorum in kiwifruit leaves. Plant Pathol. 46: 716-721.

Schroeder, C. A. and Fletcher, W. A. 1967. The Chinese gooseberry (Actinidia chinensis) in New Zealand. Econ. Bot. 21:81-92.

Sommer, N. F. and Beraha, L. 1975. Diaporthe actinidiae, a new species causing stem-end rot of Chinese gooseberry fruits. Mycologia 67: 650-653.

Tanbara, K. 1988. Kiwifruit dictionary. Japan Ehime Agricultural Cooperatives, Matsuyama, Japan. 374 pp. (In Japanese)

The Korean Society of Plant Pathology. 2009. List of plant diseases in Korea. 5th ed. The Korean Society of Plant Pathology, Seoul, Korea. 853 pp. (In Korean)

Warrington, I. J. and Weston, G. C. 1990. Kiwifruit: science and management. New Zealand Society for Horticultural Science, Auckland, New Zealand. 576 pp.

Willetts, H. J., Wong, J. A. L. and Kirst, G. D. 1980. The biology of Sclerotinia sclerotiorum, Sclerotinia trifoliorum and Sclerotinia minor with emphasis on specific nomenclature. Bot. Rev. 46: 101-165. 